\title{
"VOCÊ ESTÁ PRONTO PARA TESTAR-SE?" UMA ABORDAGEM SEMIOLINGUÍSTICA DO GÊNERO TESTE EM CORREIO FEMININO DE CLARICE LISPECTOR*
}

\author{
Leonardo Coelho Corrêa-Rosado** \\ Mônica Santos de Souza Melo ${ }^{* * *}$
}

\begin{abstract}
Resumo: O objetivo deste trabalho é configurar, a partir dos pressupostos teórico-metodológicos da AD Semiolinguística, o gênero Teste no âmbito da coletânea de textos jornalísticos de Clarice Lispector, Correio Feminino. Essa configuração observa o gênero a partir de suas restrições nos níveis situacional, discursivo e formal. Os resultados mostram que o gênero teste, no corpus em estudo, é um texto midiático que tem por finalidade propor alguns questionamentos ao interlocutor sobre aspectos ligados à sua personalidade e ao seu comportamento, através de uma série de perguntas, selecionando as visadas de informação, incitação e instrução. O gênero, em seu nível discursivo e formal, se caracteriza pela presença dos modos de organização descritivo e enunciativo, bem como por algumas construções gramaticais impessoais.
\end{abstract}

Palavras-chave: gêneros situacionais; semiolinguística; Clarice Lispector; teste.

\section{INTRODUÇÃO}

O título deste trabalho alude ao texto Você está pronta para casar-se?, que faz parte da coletânea Correio Feminino de Clarice Lispector. Tal

\footnotetext{
* Artigo integrante do projeto de iniciação científica Imagens de Mulher em Correio Feminino, de Clarice Lispector: uma abordagem semiolinguistica, financiado pelo PIBIC/CNPq/UFV, no período de agosto de 2007 a julho de 2008.

** Bolsista do PIBIC/CNPq/Universidade Federal de Viçosa (UFV), Viçosa, MG, Brasil. Graduando em Letras na UFV. Email <leonardo.rosado@ufv.br>.

*** Professora da UFV, Viçosa, MG, Brasil. Doutora em Estudos Linguísticos/Análise do Discurso. Email:<monicassmelo@yahoo.com.br>.
} 
coletânea, cujo título remete-se a uma seção feminina produzida pela escritora na década de 1960, reúne textos de Clarice Lispector publicados nas colunas e/ou seções femininas "Entre Mulheres", "Correio Feminino - Feira de Utilidades" e "Só para Mulheres", para os jornais cariocas, Comício, Correio da Manhã e Diário da Noite, respectivamente.

Como se trata de uma coletânea de textos jornalísticos, o nosso objetivo com este trabalho é configurar um dos gêneros que compõem a mesma. O gênero escolhido é o gênero teste, que se apresenta em três textos: Teste de Polidez, publicado na coluna "Só para Mulheres", em 08 de junho de 1960; Você está pronta para casar-se?, também publicado na coluna feminina "Só para Mulheres", em 10 de agosto de 1960; e Cores e Gostos, publicado na seção "Correio Feminino - Feira de Utilidades" em 24 de agosto de 1960. A configuração do gênero escolhido se baseia nos pressupostos teórico-metodológicos fornecidos pela Teoria Semiolinguística do Discurso.

Para a realização do proposto, dividiremos este artigo em duas seções: (i) A Semiolinguística e os gêneros discursivos: uma proposta de análise e configuração, que discute os critérios utilizados por tal teoria para a abordagem e estudo dos gêneros discursivos; (ii) $O$ gênero teste e sua configuração discursiva, que, seguindo os critérios apontados na seção anterior, apresenta a configuração deste gênero no corpus em questão.

\section{A SEMIOLINGUÍSTICA E OS GÊNEROS DISCURSIVOS: UMA PROPOSTA DE ANÁLISE E CONFIGURAÇÃO}

Partindo-se do pressuposto de que falar em gêneros discursivos é falar em restrições, a Semiolinguística postula que para compreender e analisar os gêneros do discurso é necessário, em primeiro lugar, considerar que o sujeito falante, em suas práticas linguageiras, apoia-se em determinadas referências. Essas referências, constituídas através do processo de socialização do sujeito pela linguagem e da linguagem pelo sujeito, estão localizadas nas memórias que o sujeito utiliza para testemunhar a maneira pela qual as comunidades se constituem. Segundo Charaudeau (2004), três são as memórias do sujeito: (i) memória dos discursos, (ii) memória das situações de comunicação e (iii) memórias das formas de 
signos. Cada uma dessas memórias tem características próprias que se articulam para permitirem ao sujeito falante utilizá-las como referências, ao se dotar de gêneros empíricos e ao erigi-los em normas de conformidade linguageira, associando-os a lugares de prática social mais ou menos institucionalizados.

Em segundo lugar, é necessário analisar os gêneros do discurso por meio de uma teoria do fato linguageiro ou do discurso, que permita conhecer os princípios gerais do ato de linguagem e os mecanismos que colocam esses princípios em funcionamento.

No nível dos princípios gerais, a Semiolinguística observa que a atividade de linguagem é fundada por quatro princípios: (i) princípio de alteridade, (ii) princípio de influência, (iii) princípio de regulação e (iv) princípio de relevância.

Já em relação ao nível dos mecanismos, a Teoria observa que eles são responsáveis por um duplo funcionamento: por um lado, os mecanismos estruturam o domínio de prática social, ou, no dizer de Charaudeau (2004), domínio de prática linguageira - um domínio muito extensivo e englobante que não permite marcar regularidades discursivas - em dominio de comunicação; por outro lado, os mecanismos ordenam à discursivização, caracterizada como um conjunto de procedimentos discursivos, separados em procedimentos discursivos propriamente ditos e procedimentos formais.

Nesse sentido, temos que o conceito de gênero, no âmbito da Teoria, constitui-se por meio de três níveis, que possuem uma articulação entre si. São eles: (i) nível das restrições situacionais, (ii) nivel das restrições discursivas e (iii) nivel das restrições formais.

\subsection{Nível das restrições situacionais}

O nível das restrições situacionais determina a expectativa (enjeu) da troca linguageira, uma vez que elas são instituídas a partir da situação de comunicação. Essa situação de comunicação determina, por meio de seus componentes, as condições de produção e de interpretação dos atos de comunicação. Essa mesma situação é ainda responsável por estruturar o domínio de prática linguageira em domínio de comunicação. Tal domínio é compreendido por Charaudeau (2004) como: 
[...] de alguma forma a resultante de todas as situações de comunicação que lhe dizem respeito, ele é ao mesmo tempo, e por efeito de retorno - o lugar onde se encontram as condições gerais às quais devem satisfazer os componentes das diferentes situações de comunicação particular das quais fazem parte. (CHARAUDEAU, 2004, p. 26)

Logo, todos os componentes de uma situação de comunicação particular devem, obrigatoriamente, inscrever-se no nível dos dados gerais que constituem o seu domínio e, ao mesmo tempo, trazer algumas especificações para ele.

Além do mais, o fato de um domínio de comunicação constituirse de certo número de condições às quais as situações de comunicação devem satisfazer, permite-nos falar em contrato de comunicação.

Assim, entendemos que há um contrato global de comunicação, que define um determinado domínio de comunicação, e algumas variantes deste contrato, ou subcontratos, definidos pelas situações de comunicação particulares.

Dentre os componentes da situação de comunicação, temos:

a) Finalidade: Charaudeau (2006a) define a finalidade como a categoria que ordena $\mathrm{o}$ ato de linguagem em função de um objetivo, obrigando os parceiros da troca a responderem a seguinte pergunta "estamos aqui para dizer o quê?". Essa finalidade é ainda entendida como um dos elementos essenciais na constituição da expectativa (enjeu) da troca linguageira, uma vez que ela determina a orientação discursiva de toda a situação de comunicação. Além disso, a finalidade, para concretizar a expectativa (enjeu) da troca, seleciona uma ou mais visadas; ${ }^{1}$

b) Identidade dos participantes: é a categoria que depende diretamente dos sujeitos que se acham inscritos e engajados na troca linguageira, sendo definida pelas perguntas "quem troca com

\footnotetext{
${ }^{1}$ Segundo Charaudeau (2004), visada é a "[...] intencionalidade psico-sócio-discursiva que determina a expectativa (enjeu) do ato de linguagem do sujeito falante e, por conseguinte, da própria troca linguageira" (p. 23). Assim, as visadas são atitudes enunciativas de base que são definidas tanto pela intenção comunicativa do $E U_{c}$ (sujeito comunicante), com relação à identidade que ele assume dentro da situação de comunicação, quanto pela identidade que ele atribui ao TUi (sujeito interpretante), nessa mesma situação.
}

CORRÊA-ROSADO; MELO - "Você está pronto para testar-se?"... 
quem?", "quem fala com quem?", “quem se dirige a quem?”, em termos que variam dos traços de natureza social aos traços de status social (CHARAUDEAU, 2006a);

c) Propósito: Charaudeau (2006a) demonstra que o propósito é a categoria que requer que todo ato de linguagem seja construído em torno de um domínio de saber, respondendo à pergunta "do que se trata?". É, portanto, “aquilo de que se fala, o projeto que se tem em mente ao tomar a palavra; o que é, afinal proposto" (CHARAUDEAU, 2006b, p. 187);

d) Circunstâncias materiais, ou condições materiais da comunicação, constituem o dispositivo material em que um gênero se realiza. Charaudeau (2006a, p. 104) aponta que "[...] a cada situação de comunicação [...], associa-se um dispositivo particular que constitui as condições materiais ad hoc de realização do contrato". Desse modo, o dispositivo material é o ambiente, o quadro, o suporte físico da mensagem. Ele é caracterizado por um material, ou seja, por elementos que estão organizados em sistemas semiológicos (sistema fônico, sistema gráfico, sistema mimogestual, sistema icônico) permitindo a configuração das unidades de sentido; por um suporte, um elemento material que funciona como um canal de transmissão do gênero, não sendo, entretanto, indiferente à mensagem; por uma tecnologia, isto é, a maquinaria utilizada para regular a relação entre os elementos do material e do suporte. Para a apreensão das características materiais desse dispositivo Charaudeau (1992, 2004, 2006a) propõe um conjunto de perguntas: "os parceiros estão presentes fisicamente?"; "eles se veem?”; "eles são únicos ou múltiplos?”; "que canal - oral on gráfico - é por eles utilizado?"; "que outro código semiolinguistico é por eles utilizado?"; etc.

\subsection{Nível das restrições discursivas}

O nível das restrições discursivas mantém com o primeiro, o das restrições situacionais, uma relação de causalidade, uma vez que esse último determina o quadro do tratamento linguageiro ou construção discursiva, que constitui ele mesmo a configuração deste nível. 
Nesse sentido, podemos compreender os componentes do nível das restrições situacionais como dados externos que, respondendo a questão do "estamos aqui para dizer o quê?", produzem instruções para um "como dizer?". Logo, o nível das restrições discursivas é o nível das atividades de ordenamento do discurso.

Os dados externos são ordenados no quadro do tratamento linguageiro através de uma correspondência entre eles e as restrições discursivas. Isso ocorre pelo fato de que os dados só têm razão de ser quando se realizam em discurso. Essa correspondência se estabelece da seguinte forma: os dados da finalidade, com as suas visadas, determinam os modos enoncivos (descritivo, narrativo e argumentativo); os dados de identidade determinam os modos enunciativos (alocutivo, elocutivo e delocutivo); os dados do propósito determinam os modos de tematização (organização dos temas e sub-temas do gênero); e os dados circunstanciais determinam os modos de semiologização (mise en scène material, verbal ou visual, do gênero).

\subsection{Nível das restrições formais}

Charaudeau (1992) entende que:

texto é o resultado material do ato de comunicação. Ele testemunha as escolhas conscientes (ou inconscientes) que o sujeito falante tem feito dentro das categorias da lingua e dos Modos de organização do discurso em função das restrições impostas pela situação. (CHARAUDEAU, 1992, p. 634 - nossa tradução)

Pela definição de texto acima apresentada, percebemos que ele é caracterizado pelo fato de ser o resultado do ato de comunicação, pelo fato de ser produzido por um sujeito particular e pelo fato de ser caracterizado por categorias de língua e modos de organização discursivos.

O fato de ser o resultado de um ato de comunicação explica como os dados da situação de comunicação condicionam as formas, por meio das restrições discursivas. $\mathrm{O}$ ato de comunicação é um todo composto de um circuito externo (fazer) e um circuito interno (dizer). O circuito externo constitui-se dos aspectos situacionais do ato e são eles que instruem a discursivização, isto é, a constituição dos procedimentos 
semiodiscursivos que vão resultar no circuito interno. ${ }^{2}$ Logo, não há muito o que dizer sobre a correlação entre o nível situacional e o nível formal, a não ser o fato de que, na aprendizagem da linguagem, as formas de uso são apropriadas progressivamente até se tornarem rotineiras e se fixarem em "maneiras de dizer". Além disso, essas formas que exprimem as normas sociais impostas pelo quadro situacional podem, em cada gênero, ser objeto de variantes.

O fato de ser produzido por um sujeito particular permite entender porque um determinado texto é sempre singular. Mesmo que esse sujeito seja, em algum nível, sobredeterminado por aspectos culturais coletivos (imaginários sociais), ele tem a sua subjetividade, que lhe permite construir um texto diferente de outro.

Já o fato de ser caracterizado por categorias de língua e por modos de organização do discurso é o que explica a diversidade que um texto pode apresentar em seu nível discursivo e formal. Como bem apontou Charaudeau (1992), todo texto é sempre heterogêneo, pois ele pode apresentar vários modos de organização em sua composição.

Além disso, esse último nível é caracterizado pelos seguintes domínios formais:

a) Mise en scène textual: entendido por Charaudeau (2004) como a disposição do paratexto;

b) Composição textual interna: organização do texto em partes (um artigo científico, por exemplo, é organizado basicamente em introdução, metodologia, resultados e discussões, considerações finais e referências);

c) Fraseologia: emprego recorrente das locuções breves e outras expressões fixas;

d) Construção gramatical: recorrência dos tipos de construção (ativa, passiva, impessoal, imperativa), das marcas lógicas, da pronominalização, da anaforização, da modalidade, etc.

\footnotetext{
${ }^{2}$ Como bem apontou Charaudeau (2004, p. 29), entre os componentes situacionais, as circunstâncias materiais são as que influenciam mais diretamente as formas, já que elas constituem-se dos dispositivos materiais.
} 
É dessa forma que percebemos que as restrições formais funcionam, na verdade, como índices daquilo que as restrições discursivas e situacionais ordenam.

Portanto, o conceito de gênero proposto pela Semiolinguística permite fazer uma articulação entre os três níveis que compõem um determinado gênero: o nível situacional, o nível discursivo e o nível formal. Nesse sentido, são os componentes dos três níveis de restrições que constituem os critérios para caracterizar os gêneros do discurso. Entretanto, pelo fato de as características do discurso dependerem essencialmente de suas condições de produção situacionais, fala-se então de "gêneros situacionais" e as variantes deles de "subgêneros".

Essa articulação deve ser entendida ainda como uma correlação e não como uma implicação sucessiva entre os diversos níveis, pois todos os níveis possuem classificações e critérios que permitem apreender um determinado gênero, não restringindo a questão dos gêneros a somente um dos níveis.

\section{O GÊNERO TESTE E SUA CONFIGURAÇÃO DISCURSIVA}

Conforme aponta Charaudeau (2004), um domínio de comunicação determinado constitui-se como o resultante de todas as situações de comunicação que lhe dizem respeito, sendo, por isso, o lugar onde se encontram as condições gerais que uma situação de comunicação particular deve satisfazer. Nesse sentido, uma configuração e análise de gênero, que tomem como base esta proposta, devem partir desse ponto, visto que, além de ajudar a compreender outros aspectos do gênero, ele serve, nas interações linguageiras, como ponto de referência, tanto para o sujeito comunicante, quanto para o sujeito interpretante.

Considerando o exposto, fizemos, em princípio, a seguinte pergunta: qual seria o domínio de comunicação do gênero Teste, no corpus em estudo?

A justificativa para esta pergunta reside no fato de que, em primeiro lugar, Correio Feminino consiste em uma coletânea de textos jornalísticos, ou seja, trata-se de um livro organizado, segundo alguns 
critérios e objetivos, por uma editora para a divulgação pública desses textos claricianos; em segundo lugar, os textos classificados como Teste foram, em princípio, publicados nas colunas/seções femininas de Clarice Lispector, e, desta forma, são considerados por Nunes (2006) como textos pertencentes à imprensa feminina, isto é, textos veiculados na mídia de imprensa (suporte jornal). ${ }^{3}$ Teríamos, então, dois critérios que são opostos entre si, uma vez que se considerarmos o gênero Teste no âmbito da coletânea Correio Feminino, o domínio de comunicação seria um domínio que iria dar conta de uma situação de comunicação mais literária, visto que os gêneros ali publicados se encontram transpostos de uma situação de comunicação específica para outra que pretende divulgar publicamente esses textos; enquanto se considerarmos o gênero Teste no âmbito das colunas femininas, o domínio de comunicação seria, por sua vez, o domínio midiático, visto que os gêneros seriam analisados em seu contexto real de publicação, isto é, o contexto das colunas/seções femininas e sua relação com o jornal.

Assim, tivemos que decidir qual critério adotar: faríamos uma análise que consideraria o gênero no âmbito da coletânea ou faríamos uma análise que consideraria o gênero no âmbito das colunas? Optamos por fazer uma análise que leva em conta o contexto das colunas em si. Entretanto, esse contexto como um todo não pode ser apreendido, uma vez que a transposição de um gênero de um suporte para outro acarreta mudanças em algumas de suas funções, principalmente aquelas relacionadas às restrições situacionais. Assim, os gêneros vistos do ponto de vista da coletânea têm, em termos de restrições situacionais, características específicas, tais como a finalidade de divulgar os textos, o suporte "livro" (circunstâncias materiais), etc.; enquanto os gêneros, vistos do ponto de vista das colunas, possuem outra finalidade e outras

\footnotetext{
${ }^{3}$ Nunes (2006) aponta que nas três colunas/seções femininas que Clarice Lispector produziu para os jornais cariocas Comício, Correio da Manbã e Diário da Noite, nas décadas de 1950 e 1960, não há nenhuma referência ao seu nome, pois a escritora ou utilizava-se de pseudônimos - é o caso da coluna feminina "Entre Mulheres" do tabloide Comício, em que Clarice assinava com o nome de Tereza Quadros, e da seção feminina “Correio Feminino - Feira de Utilidades” em que Lispector utilizava o pseudônimo Helen Palmer - ou era ghostwriter de alguma celebridade - caso esse da coluna "Só para Mulheres" do jornal Diário da Noite, na qual Clarice escrevia os textos para Ilka Soares, famosa atriz, modelo e vedente da década de 1960. Tais informações serão relevantes principalmente para a apreensão das identidades dos sujeitos do gênero que será exposta mais adiante.
} 
características em termos de restrições situacionais, principalmente referentes ao suporte, ou seja, às circunstâncias materiais.

Feito a seleção de critério para tratar do domínio de comunicação e consequentemente das restrições situacionais, temos que o gênero Teste aparece no âmbito das colunas femininas de Clarice Lispector. Assim, considerando tais informações, apontamos que o domínio de comunicação com o qual estamos lidando é o domínio midiático, ou seja, o fato do gênero Teste aparecer no âmbito das colunas femininas de Clarice, e essas estarem vinculadas à mídia de imprensa, ou seja, ao suporte jornal, permite-nos concluir que estamos diante de um domínio de comunicação midiático. Entretanto, como se configura esse domínio midiático?

\subsection{O domínio de comunicação midiático e a imprensa feminina}

Dentre as atividades discursivas realizadas pelos seres humanos em suas práticas linguageiras, a atividade de informar constitui-se como uma atividade geral, realizada por qualquer ser humano em várias situações de comunicação. No entanto, no seio social, esta atividade geral pode se transformar em uma espécie de propriedade particular de um domínio particular, a que chamamos de domínio das mídias ou domínio midiático. ${ }^{4}$ Isso ocorre pelo fato de que o objetivo das mídias é informar o cidadão sobre os acontecimentos do mundo, ou seja, nas mídias, é o discurso de informação que a constitui, da mesma forma que no domínio político é o discurso político e no domínio literário, o discurso literário.

\footnotetext{
4 O termo mídia abrange, na atualidade, diversas acepções. Em um sentido mais restrito, usado no âmbito das ciências da comunicação, o termo "designa os meios (ou o conjunto dos meios) de comunicação: jornais, revistas, tv, rádio, cinema, etc.” (RABAÇA; BARBOSA, 1995, p. 401), ou seja, refere-se aos meios (suportes) que têm a função de comunicar. Em um sentido mais amplo, mídia é "um suporte organizacional que se apossa dessas noções [informação e comunicação] para integrá-las em suas diversas lógicas - econômica (fazer viver uma empresa), tecnológica (estender a qualidade e a quantidade de sua difusão) e simbólica (servir à democracia cidadã)" (CHARAUDEAU, 2006a, p. 15 grifos nossos). Neste sentido, a mídia, ou as mídias, não seria uma instância de poder, visto que ela não promulga nenhuma regra de comportamento, nenhuma norma, nenhuma sanção; mas uma instância ou um domínio social que impõe, por meio de suas práticas discursivas, o que constrói do espaço público. No âmbito deste trabalho, utilizamos o termo mídia nessas duas acepções: quando nos referirmos aos suportes midiáticos, como a televisão, o jornal e o rádio, falaremos de mídia em seu sentido restrito; quando nos referirmos ao domínio midiático, falaremos da mídia em seu sentido mais amplo.
}

CORRÊA-ROSADO; MELO - "Você está pronto para testar-se?"... 
Assim, a informação, enquanto discurso das mídias, é responsável por uma transmissão de saber, saber esse que se constrói no interior de um processo de representação do mundo, por um alguém que o possui a alguém que se presume não possuí-lo. Deste modo, além de lidar com uma lógica econômica, que faz com que o organismo de informação aja como uma empresa que fabrica um produto e coloca esse produto no mercado de bens de consumo, com uma lógica tecnológica, que faz com que o organismo de informação procure estender a qualidade e a quantidade de sua difusão, ela lida com uma lógica simbólica, que Charaudeau (2006a) compreende da seguinte forma:

trata-se da maneira pela qual os indivíduos regulam as suas trocas sociais, constroem representações dos valores que subjazem a suas práticas, criando e manipulando signos e, por conseguinte, produzindo sentido. (CHARAUDEAU, 2006a, p. 16)

O fato de o domínio midiático lidar com essas três lógicas na construção de um saber permite-nos compreender as mídias como suportes organizacionais especializados em informar e comunicar. Sua organização configura-se por meio de um aparelho, a que denominamos de aparelho midiático ou máquina midiática (CHARAUDEAU, 2006a). Tal aparelho constitui-se dos seguintes lugares: (i) instância de produção, ou instância midiática; (ii) instância de recepção, ou público; e (iii) Produto. ${ }^{5}$

A instância midiática é responsável por fornecer informações, visto que seu objetivo, enquanto componente do domínio midiático, é fazer saber, bem como por propulsionar o desejo de consumir, uma vez que ela depende do desejo que ela propulsiona no consumidor para se manter enquanto empresa. Essa mesma instância, para dar conta da complexidade de seus objetivos, desdobra-se em dois conjuntos: (i) um externo-externo, composto pelos atores do sistema de produção (aí incluído diretores, redatores, operadores técnicos, etc., ou seja, os membros de uma empresa jornalística), compreende as condições socioeconômicas da instância midiática enquanto empresa; e (ii) outro, externo-interno, composto pelo(s) organizador(es) da enunciação

\footnotetext{
${ }^{5} \mathrm{O}$ termo instância evidencia que a quantidade de atores envolvidos, tanto na produção quanto na recepção do gênero, não é um, ou seja, um locutor, na instância de produção e um interlocutor, na instância de recepção (relação 1/1), mas na verdade vários, que compõem o que Charaudeau (2006a) denomina de entidades compósitas (relação n/n).
} 
discursiva da informação (aquele(s) que assina(m) o texto, que, para maioria dos casos, é(são) o(s) jornalista(s)), compreende as condições semiológicas de produção. Ambos os conjuntos constituem-se como um universo de práticas linguageiras, nas quais os atores estão engajados na concretização de um projeto comum. Por isso, podemos falar que, na instância midiática, os atores:

[...] contribuem para fabricar uma enunciação aparentemente unitária e homogênea do discurso midiático, uma co-enunciação, cuja intencionalidade [...] corresponde a um projeto comum a esses atores e do qual se pode dizer que representa a ideologia do organismo de informação. (CHARAUDEAU, 2006a, p. 73)

A instância de recepção, por sua vez, é responsável pela manifestação de seu interesse ou prazer em consumir o que a instância midiática informa. Constitui-se, neste sentido, no consumidor da informação. E, da mesma forma que a instância midiática, a instância de recepção é composta por dois conjuntos: (i) um, interno-externo, que se configura como o destinatário-alvo, visualizado pela instância midiática como aquele susceptível de perceber os efeitos de sentido visados por esta última; e (ii) outro, externo-externo, que se configura como o próprio público, real consumidor das informações.

Já o produto se apresenta como o lugar em que o discurso de informação se configura como texto. Tal texto é organizado através da combinação de formas linguísticas, icônicas, gráficas e gestuais, que são colocadas no discurso através de procedimentos discursivos diversos. Ele é também o resultado do ato de linguagem de informação midiática, e, por esse motivo, ele apresenta traços que remetem às condições contratuais na qual ele é produzido.

Em termos contratuais, o domínio midiático se configura da seguinte forma:

a) Identidade: no domínio midiático, os sujeitos estão engajados em uma das duas instâncias acima referidas: (i) instância de produção ou instância midiática e (ii) instância de recepção ou público. Essas duas instâncias estão relacionadas uma com a outra através do produto; 
b) Finalidade: nas situações de comunicação midiática, situações essas que estruturam o domínio midiático, a finalidade consiste em uma tensão entre um faz̧er saber (visada de informação) e um fazer fazer (visada de incitação), pois a instância midiática, da qual emerge um determinado ato de comunicação midiático, tende, a um só tempo, a "produzir um objeto de saber segundo uma lógica cívica: informar o cidadão" e "[...] produzir um objeto de consumo segundo uma lógica comercial: captar as massas para sobreviver à concorrência" (CHARAUDEAU, 2006a, p. 86);

c) Propósito: na tensão entre o fazer saber e o faz̧er fazer, tensão essa que, de um lado, tende para a veracidade, por meio de uma "austeridade racionalizante" e, de outro lado, para a captação do grande público, através de uma "imaginação dramatizante", a instância midiática recorta um acontecimento, transformando-o, por meio do processo de transformação, de um mundo a comentar em um mundo comentado. Ao transformar o acontecimento em estado bruto em um acontecimento midiaticamente construído, a instância midiática o faz visando sempre um determinado alvo, o destinatário-alvo (processo de transação). Porém, a instância de recepção pode, por sua vez, reestruturar o fato, conforme as suas próprias representações discursivas e competências cognitivas de interpretação (processo de interpretação);

d) Circunstâncias materiais: as situações de comunicação que resultam em um domínio de comunicação realizam-se em condições materiais específicas. Tal fato permite-nos entender, conforme já apontado, como o ambiente físico no qual um determinado ato de linguagem se realiza impõe algumas restrições, de ordem material, para a realização deste ato. É assim que o dispositivo material de enunciação, que constitui o suporte físico de uma mensagem, determina sua formatação, conferindolhe sentido. Esse mesmo dispositivo articula vários elementos, o material, o suporte e a tecnologia, formando um conjunto estruturado pela solidariedade combinatória que os liga. No que concerne ao domínio midiático, esses componentes permitem distinguir três grandes suportes de mídia: (i) rádio, também denominado de 
mídia radiofônica, (ii) televisão, ou mídia televisiva; (iii) imprensa escrita, ou mídia de imprensa.

Dentro da mídia de imprensa, vemos que o aspecto material do dispositivo é, na verdade, uma área escritural, que não só envolve a escrita, em si, feita de palavras, mas também, elementos visuais, tais como fotos, desenhos, figuras, além de gráficos e iconogramas. Toda essa área escritural é posta sobre um papel, que não tem uma função passiva com relação à configuração do produto, mas uma função ativa que o determina e é determinada por ele. Deste modo, podemos afirmar que o suporte material, juntamente com esse aspecto escritural, além da tecnologia que a mídia de imprensa utiliza, são responsáveis por algumas características básicas dos seus produtos: (i) ausência física, tanto da instância midiática quanto da instância de recepção, fazendo com que os acontecimentos noticiados entrem numa relação de assincronia, ou seja, o tempo entre o acontecimento e a escritura, e entre a escritura e a recepção, não correspondem ao mesmo tempo; (ii) alta atividade de conceitualização, tanto de uma instância quanto da outra; em outras palavras, a capacidade analítica tanto da instância midiática, quanto da instância de recepção, é maior nos textos escritos do que nos textos orais, visto que o que se encontra "preto no branco" torna-se mais fácil para se avaliar; (iii) possibilidade de retorno ao que foi escrito, que é uma consequência da alta atividade de conceitualização acima comentada, pois "a escrita desempenha o papel de prova para a instauração da verdade, o que não é possível para a oralidade, não recuperável e aparentemente efêmera" (CHARAUDEAU, 2006a, p. 113).

As informações acima arroladas possibilitam-nos entender como as situações de comunicação midiática irão estruturar-se em nível mais geral. Em outras palavras, toda situação de comunicação particular, que se diz midiática, deverá satisfazer as condições acima, pois, como já apontamos, um domínio de comunicação consiste no resultante das situações de comunicações particulares que lhe pertencem.

Assim, com relação ao domínio midiático, as situações particulares de comunicação midiática devem, em princípio, possuir duas instâncias, uma de produção outra de recepção, que estão ligadas uma a outra por meio de um produto, sendo que a primeira tem como finalidade informar a segunda sobre um determinado acontecimento do mundo. $\mathrm{O}$ 
produto está sempre associado a um suporte, ora televisivo, ora radiofônico, ora de imprensa. Tais informações mostram, portanto, que a atividade capital do domínio midiático é a prática de informação.

O nosso corpus, isto é, os textos da obra Correio Feminino, situam-se no âmbito desse domínio. Logo, esses textos, independente do gênero que eles apresentam, devem, de uma maneira geral, satisfazer essas condições, embora possam ser particularizados em suas devidas situações de comunicação. Entretanto, os textos de nosso corpus mantêm uma relação com o domínio midiático através de um elemento intermediário: as colunas femininas.

Conforme os trabalhos de Nunes (2006, 2008), os textos veiculados nas colunas femininas, "Entre Mulheres", "Correio Feminino - Feira de Utilidades" e "Só para Mulheres", constituem exemplos de textos pertencentes à imprensa feminina. O termo imprensa feminina é um termo utilizado pelas Ciências da comunicação para designar os tipos de publicações dirigidos e pensados para as mulheres. Desse modo, o sexo do público ao qual a imprensa feminina se dirige faz parte de sua natureza conceitual. No Brasil, os trabalhos de Buitoni (1981, 1986) apresentam informações valiosas sobre esse tipo de imprensa.

As informações arroladas por Buitoni nesses trabalhos mostram que a finalidade da imprensa feminina não é apenas informar o cidadão, mas também entretê-lo com diversos assuntos, que, por seu turno, podem ter alguma ligação com a atualidade. Considerando esse contexto, perguntamo-nos: o fato da imprensa feminina não lidar diretamente com o discurso de informação a extingue do domínio midiático? Se "sim", a imprensa feminina constituiria, então, um domínio a parte? Se "não", como incluí-la neste domínio e onde ela estaria situada? E os gêneros dessa imprensa satisfazem o contrato global de comunicação midiático que propomos acima?

Comecemos pela primeira pergunta. Para ela, vamos considerar o fato de que todo domínio, seja ele qual for, é caracterizado por diversas práticas discursivas, embora sempre haja uma prática predominante a qual as outras práticas se associam. No caso do domínio midiático, a prática discursiva dominante é a prática de informação que pode estar associada a outras práticas, tais como a de entretenimento. A figura 1, 
apresentada a seguir, tenta explicar a relação deste domínio com suas práticas:

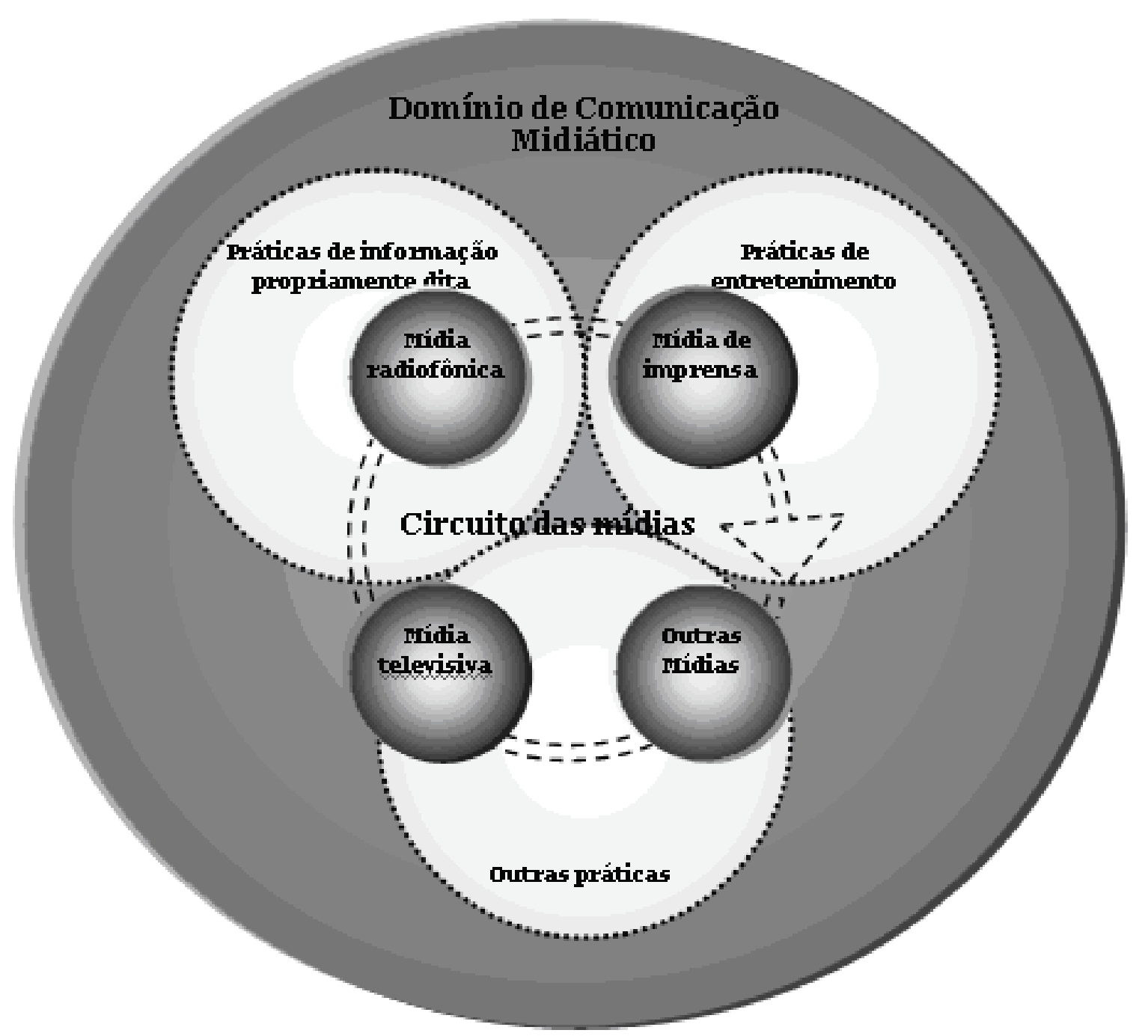

Figura 1 - Domínio Midiático e suas práticas.

$\mathrm{Na}$ figura 1, o círculo maior é o domínio midiático. Nele se encontram as práticas discursivas, representadas pelos círculos médios, que constituem as atividades linguageiras em que os atores da instância midiática e de recepção estão engajados. Dentre as práticas que destacamos, há a prática de informação propriamente dita, a prática de entretenimento e outras que rotulamos como outras práticas. As duas primeiras, prática de informação e prática de entretenimento, são as que mais caracterizam o domínio midiático, enquanto as outras práticas ocorrem em situações bem especiais, como as práticas de investigação, para os 
gêneros que lidam com um aspecto investigativo, como a reportagem. A seta em círculo pontilhada representa o que denominamos de circuito das mídias. Como afirmamos anteriormente, o termo mídia pode ser entendido, neste trabalho, como um meio de comunicação (suporte) que veicula diversos gêneros ou situações de comunicação particulares. Cada mídia pode adotar todas essas práticas que estamos apresentando, e, dessa forma, não há uma associação entre um tipo de mídia e um tipo de prática. Daí utilizarmos o termo circuito, representando-o por uma seta pontilhada, visto que esse circuito está a todo o momento "girando" sobre essas práticas. E dentro de cada mídia, há as situações de comunicação particulares que irão apresentar os dados gerais, tanto do domínio quanto da prática a que elas se vinculam.

Pelo fato de a imprensa feminina, como apontou Buitoni (1986), ser um conceito sexuado, isto é, um conceito no qual o público de suas publicações faz parte da natureza de sua definição, sua localização no âmbito do domínio midiático não se faz nem no nível do circuito das mídias (embora o termo imprensa feminina possa, num primeiro momento, estar relacionado com a mídia de imprensa, as práticas da imprensa feminina ocorrem em qualquer tipo de mídia, o que nos leva a entender o porquê da imprensa feminina não poder ser um suporte midiático, tal como definido aqui), nem no nível das práticas midiáticas (pois mesmo que a prática de informação não seja um aspecto forte da imprensa feminina, como apontou Buitoni (1986), há alguns casos em que ela aparece conjuntamente às práticas de entretenimento), mas no nível do domínio midiático em si, pois é nele que encontramos o público ao qual a imprensa feminina se dirige. Trata-se de um público selecionado, um público feminino, um público visualizado pela instância midiática como aquele que será capaz de compreender os sentidos que ela tenta promover.

Portanto, a resposta para a primeira pergunta é que a imprensa feminina não constitui um domínio de comunicação à parte, diferente do midiático e dos demais domínios, tais como o político, o literário, o publicitário etc. ${ }^{6}$ Ela seria, dessa forma, uma espécie de segmentação,

6 Mesmo o fato de algumas revistas ou jornais femininos terem algumas seções dedicadas à literatura, a finalidade desses textos não permite compreender a imprensa feminina como pertencente ao domínio literário, pois as visadas selecionadas para este componente do contrato 
em nível de público, do domínio midiático, que utiliza, basicamente, a prática discursiva de entretenimento como um de seus aspectos mais característicos.

Além do mais, para que a imprensa feminina constituísse um domínio à parte seria necessário que o contrato global de comunicação dela fosse diferente do contrato global de comunicação midiático, assim como diferente dos outros contratos de comunicação dos demais domínios. No caso da imprensa feminina, todos os componentes de seu "contrato" se assemelham aos componentes do contrato midiático. Mesmo no caso da finalidade, que embora não seja propriamente informar o público sobre algum acontecimento do mundo fenomênico, e sim entretê-lo com assuntos de moda, beleza, saúde, educação, etc., a informação aparece como um de seus aspectos, uma vez que, quando se entretém, também se informa. Porém, a informação, no âmbito da imprensa feminina, não pode ser vista da mesma forma que as informações das práticas de informação midiática propriamente ditas; nessa há, como postula Buitoni (1986), uma ligação com o factual, enquanto naquela há uma ligação com o atual.

Para a segunda pergunta que propomos, ou seja, aquela relacionada com a questão dos gêneros produzidos no âmbito da imprensa feminina, o próprio raciocínio lógico de nossos apontamentos permite compreender que tais gêneros vão satisfazer as condições gerais do contrato de comunicação midiático. A única restrição que apontamos é com relação à finalidade e à instância de recepção.

A restrição com relação à instância de recepção reside na segmentação do público. Já para a finalidade, o contrato global de comunicação midiático prevê que as situações de comunicação midiática devem ter por finalidade informar alguém sobre algum fato, selecionando para isso duas visadas: uma de informação, outra de incitação. No âmbito da imprensa feminina, à finalidade de informar se junta outra finalidade, a de entreter, selecionando, geralmente, não duas, mas três visadas: (i) uma visada de informação, ou seja, um "fazer saber", (ii) uma visada de incitação, isto é, um "fazer fazer", e (iii) uma visada de instrução, ou seja, um "fazer saber-fazer". A visada de instrução entra como um de

global midiático são diferentes daquelas que constituem o contrato global de comunicação literário.

CORRÊA-ROSADO; MELO - "Você está pronto para testar-se?"... 
seus aspectos característicos pelo fato de que, muitos dos textos produzidos na imprensa feminina terem um caráter orientacional, que propõem um modelo de mulher a ser seguido pelas leitoras/ouvintes.

\subsection{O gênero Teste e suas restrições situacionais: uma questão de contrato}

A primeira categoria a se considerar em uma restrição situacional é a finalidade. A finalidade tenta sempre responder a pergunta "estamos aqui para dizer o quê?", determinando como isso a expectativa (enjeu) de uma situação de comunicação. Com relação ao Teste, dentro de nosso corpus e do domínio considerado, sua finalidade é fazer com que o interlocutor averigue, através de uma série de perguntas propostas pelo locutor, se ele apresenta ou não certos traços de personalidade ou de comportamento requeridos pela ordem social dominante, principalmente àqueles ligados ao perfil da mulher. Para a realização dessa finalidade, o sujeito enunciador seleciona três visadas:

a) visada de informação, que Charaudeau (2004) define como:

en quer 'fazer saber', e ele está legitimado em sua posição de saber; tu se encontra na posição de 'dever saber' alguma coisa sobre a existência dos fatos, ou sobre o porquê ou como de seu surgimento (p. 23-24).

Nos textos caracterizados como uma situação midiática de Teste, a visada de informação existe quando, ao perguntar e testar o destinatário sobre algum aspecto ligado ao seu comportamento e a sua personalidade, o enunciador informa, pelas respostas das perguntas, quais são os padrões relacionados às regras de comportamento e aos aspectos de personalidade que devem ser seguidos pelas mulheres. Logo, a visada de informação está intrinsecamente ligada às respostas, apresentadas na seção de respostas do gênero, que o sujeito enunciadordisponibiliza. ${ }^{7}$ Vejamos alguns exemplos:

\footnotetext{
${ }^{7}$ Como veremos mais adiante, o sujeito enunciador (EUe) desdobrar-se em um outro sujeito enunciador, a que denominamos de sujeito enunciador (2) (EUe (2)). Porém, nesse momento de configuração do gênero Teste, falamos de sujeito enunciador de forma geral, sem levar em conta as complexidades relacionadas à organização enunciativa deste gênero.
} 
(1) Que faz ele quando sua companheira cumprimenta, na rua, alguém que ele não conhece? (Diminui um pouco a marcha, para o caso da senhora querer parar um instante). (TES1)

(2) PRETO - Positivo: seu desejo é absoluto e afasta tudo mais. Negativo: só tem confiança no que faz. Indiferente: nunca renuncia às ambições. (TES3)

b) visada de incitação, na qual:

en quer 'mandar fazer' (faire faire), mas, não estando em posição de autoridade [de mandar fazer] [...] não pode senão incitar a fazer; ele deve, então, 'fazer acreditar' (por persuasão ou por sedução) ao tu que ele será o beneficiário de seu próprio ato; tu está, então, em posição de 'dever acreditar' que, se ele age, é para o seu bem. (CHARAUDEAU, 2004, p. 23)

No gênero em estudo, temos então que o EUe incita o TUd a responder as perguntas, por ele propostas, como uma forma de observar até que ponto, em termos de personalidade e comportamento, esse último está de acordo com os padrões femininos do contexto sóciohistórico ao qual a situação midiática Teste está vinculada. 8 Ao responder as perguntas, e caso perceba uma dissonância entre suas respostas e as respostas do próprio teste, o $T U d$ poderá realizar ações para corrigir as "falhas" que ele apresenta, tornando-se, com isso, um beneficiário direto da sua própria ação de responder, pois as respostas podem tanto mostrar o quanto "ela é feminina", ou o quanto ele está longe disso. Logo, a visada de incitação é uma consequência da visada de informação, porém, enquanto a primeira visa informar quais são os padrões femininos dominantes, a segunda visa a incitar o $T U d$ a realizar a ação de responder, tornando-se assim um beneficiário dela. Os exemplos (3) e (4) abaixo dão-nos uma melhor visão do exposto:

(3) Gostos e cores não se discutem - mesmo porque o seu gosto em cores revela sua personalidade. A prova disso pode-se tirar com um teste bastante simples. (TES3)

\footnotetext{
8 As siglas EUc, EUe, TUd, TUi correspondem, no âmbito da AD Semiolinguística, aos seguintes sujeitos: sujeito comunicante (EUc), sujeito enunciador (EUe), sujeito destinatário (TUd) e sujeito interpretante (TUi) (CHARAUDEAU, 1983, p. 46-47).
}

CORRÊA-ROSADO; MELO - "Você está pronto para testar-se?"... 
(4) Não seja demasiado exigente com os modos "dele". Mas, se você quiser ajudar seu marido a parecer mais polido, faça com ele esse teste, e vejam os dois em que adiantamento ele está. (TES1)

c) visada de instrução, definida como:

en quer mandar 'fazer saber-fazer', e ele se encontra ao mesmo tempo em posição de autoridade de saber fazer e de legitimação para transmitir o saber fazer; o tu está em posição de 'dever saberfazer', segundo um modelo (modelo de emprego) que é proposto pelo $e u$. (CHARAUDEAU, 2004, p. 24)

O EUe se utiliza da visada de instrução como uma forma de mostrar o procedimento de realização do Teste. Porém, a visada de instrução vai mais além do que isso, ela é como uma "agulha" que costura as duas outras visadas então apresentadas, pois, ao informar e incitar, o EUe instrui, de uma maneira muito implícita, qual são as regras de comportamento e de etiqueta vigentes.

Contextualizando as informações referentes às visadas selecionadas pelo gênero Teste através do texto Você está pronta para casar$s e$ ? (em anexo), teremos uma melhor visualização das mesmas.

Esse texto, cuja finalidade é averiguar se o TUd apresenta os comportamentos padrões para a vida a dois, isto é, para o casamento, não apresenta explicitamente uma seção resposta, como nos textos Teste de Polidez e Cores e Gostos. As respostas aqui estão implícitas, visto que todas as perguntas são sequências interrogativas de sim ou não, sequências que pressupõem uma informação implícita já conhecida pelo locutor, mas que esse, por meio das respostas, deseja ver confirmada ou invalidada pelo interlocutor. Como se trata de informações implícitas, nesse texto, esse tipo de sequência interrogativa direta pode ser comparada com as asserções que o EUe consideraria ser aquelas que estão relacionadas a uma representação do casamento vigente na época de publicação do mesmo. Logo, por trás dessas sequências, temos então a primeira visada, a visada de informação. Todas as perguntas desse texto informam sobre os padrões comportamentais que as mulheres devem ter para a situação social de casamento.

A maneira pela qual as sequências interrogativas estão estruturadas permite-nos dizer que elas incitam o $T U d$ a respondê-las, uma vez que, se o EUe deseja que as informações sobre os padrões vigentes sejam 
reconhecidas pelo o $T U d$, ele precisa incitá-lo a reconhecer esses padrões por meio de tais sequências. Por exemplo, quando se pergunta, "Vocêe $e$ seu noivo já concordaram quanto à religião?”, há uma informação implícita por detrás da sequência (Os noivos devem concordar quanto à religião), além de uma incitação quanto a se questionar se se tem ou não tal comportamento. Uma resposta negativa gera no destinatário uma consciência de que há falhas e que precisam ser sanadas.

Assim, temos também uma visada de instrução, que se apresenta não só nessa sequência, mas em todas as outras que compõem o texto. Além disso, a visada de instrução pode ser verificada num dos elementos que constituem a composição textual interna do gênero, a seção de instrução, que se localiza acima das perguntas. Vejamos:

(5) Quanto maior número de vezes você responde "sim" às perguntas que se seguem, mais pronta você está. Só vale a "sim" verdadeiro, sincero... (TES2)

No exemplo (e) acima, percebemos que o EUe instrui o TUd a como proceder quanto à realização do teste.

Mas, quem seria esse(s) Eu(s) e esse(s) Tu(s) que estão em relação de troca linguageira no gênero em questão?

Como vimos, o contrato global do domínio midiático, em termos de identidade, projeta duas instâncias, a instância de produção, ou instância midiática, e a instância de recepção, ou público. A própria instância midiática, assim como a de recepção, é composta por dois conjuntos: (i) para a instância midiática: um conjunto composto pelos atores do sistema de produção e um conjunto composto pelo(s) organizador(es) da enunciação discursiva do gênero; (ii) para a instância de recepção: um conjunto de destinatários-alvos, visualizados pela instância midiática e um conjunto composto pelo próprio público.

Contudo, como em nosso corpus o gênero situacional Teste aparece no âmbito das páginas/seções femininas de Clarice Lispector, observamos que as identidades dos sujeitos, principalmente daqueles que compõem a instância midiática, apresentam especificidades que estão relacionadas tanto com a coluna em que o texto particular aparece quanto com a assinatura apresentada na coluna. 
Dessa forma, as identidades dos sujeitos podem estar relacionadas com um dos dois tipos de esquema que propomos abaixo:

- Um esquema de mascaramento de identidade através da utilização de um determinado pseudônimo;

- Um esquema de mascaramento de identidade através do procedimento de ghostwriting.

Embora, em um aspecto global, ambos os esquemas reflitam uma forma de mascaramento identitário, há uma importante diferença entre o esquema (1) e o esquema (2): aquele se constitui no mascaramento da identidade do sujeito comunicante, ou seja, Clarice Lispector mascara a sua própria identidade através de um pseudônimo, no caso Helen Palmer; e este no mascaramento da identidade do sujeito enunciador, visto que a celebridade em questão, Ilka Soares, não era o enunciador dos textos, mas, sim, um dos componentes psicossociais da instância de produção. ${ }^{9}$

Assim, para o gênero teste, que, em nosso corpus, só aparece nas colunas "Correio Feminino - Feira de Utilidades" (1 texto) e "Só para Mulheres" (2 textos), temos os seguintes esquemas representados pelas figuras 2 e 3 .

O esquema enunciativo detalhado na figura 2 faz referência à seção feminina "Correio Feminino - Feira de Utilidades", cuja assinatura era a de Helen Palmer. Tal esquema deixa evidente, em termos de identidade, que: (i) o EUc é o conjunto de atores envolvidos na prática jornalística, tais como os diretores da empresa, os redatores, os revisores, os operadores técnicos, e a própria escritora e elaboradora dos testes, Clarice Lispector, porém, como EUc, nessa situação de comunicação, Clarice é somente uma das colaboradoras do jornal; (ii) o EUe (1) é o sujeito enunciador do teste, ou seja, aqui Clarice aparece novamente, porém não mais como uma funcionária, mas sim como o Eu que enuncia um texto dentro de uma determinada situação de comunicação; (iii) o

\footnotetext{
${ }^{9}$ Nesse segundo esquema, temos um procedimento bem complexo. Nele, Clarice precisa "passarse" por Ilka Soares: ela se apropria do que poderia ser o discurso e o universo de Ilka, valendo-se dos estereótipos de Ilka produzidos pela própria mídia. Neste sentido, as opiniões de Ilka-Clarice devem corresponder às opiniões de Ilka-Ilka, pois, caso contrário, soaria, para o interlocutor, como inverossímil tais opiniões. Assim, o estilo de Ilka deveria ser colocado em evidência, enquanto o estilo de Clarice deveria ser mascarado.
} 
EUe (2), ou o pseudônimo utilizado pelo EUe (1), é um ser estratégico que pretende encenar a existência de um ser psicossocial real (que de fato não existe), embora, na verdade, seja somente um desdobramento do EUe (1), visto que esse último deseja, por meio do primeiro, mascarar a identidade psicossocial do EUc, Clarice Lispector; (iv) o TUi, o(s) verdadeiro(s) leitor(es) do gênero, no caso as mulheres que leem essa seção feminina; (v) o TUd, o destinatário-alvo do gênero, isto é, as mulheres que precisam de informações e instruções sobre comportamento e personalidade.

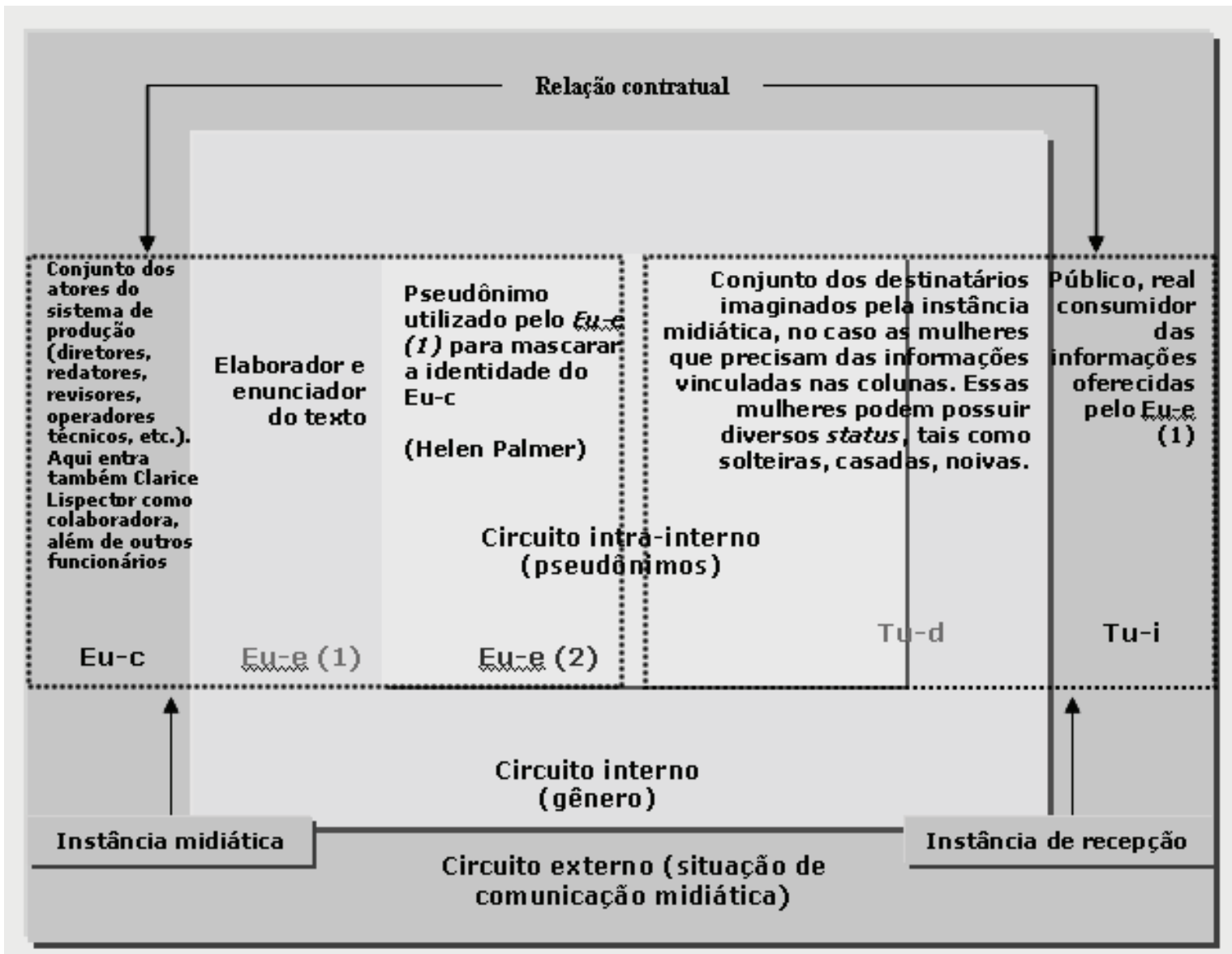

Figura 2 - Quadro enunciativo referente à seção "Correio Feminino Feira de Utilidades".

Assim, juntos, EUc, EUe (1) e EUe (2) formam o que denominamos de instância midiática do Correio da Manhã (linhas pontuadas do lado esquerdo), enquanto o TUd e o TUi são como os dois lados de uma mesma moeda, ou seja, eles compõem o que Charaudeau (2006a) denomina de instância de recep̧̧ão dos gêneros midiáticos. 


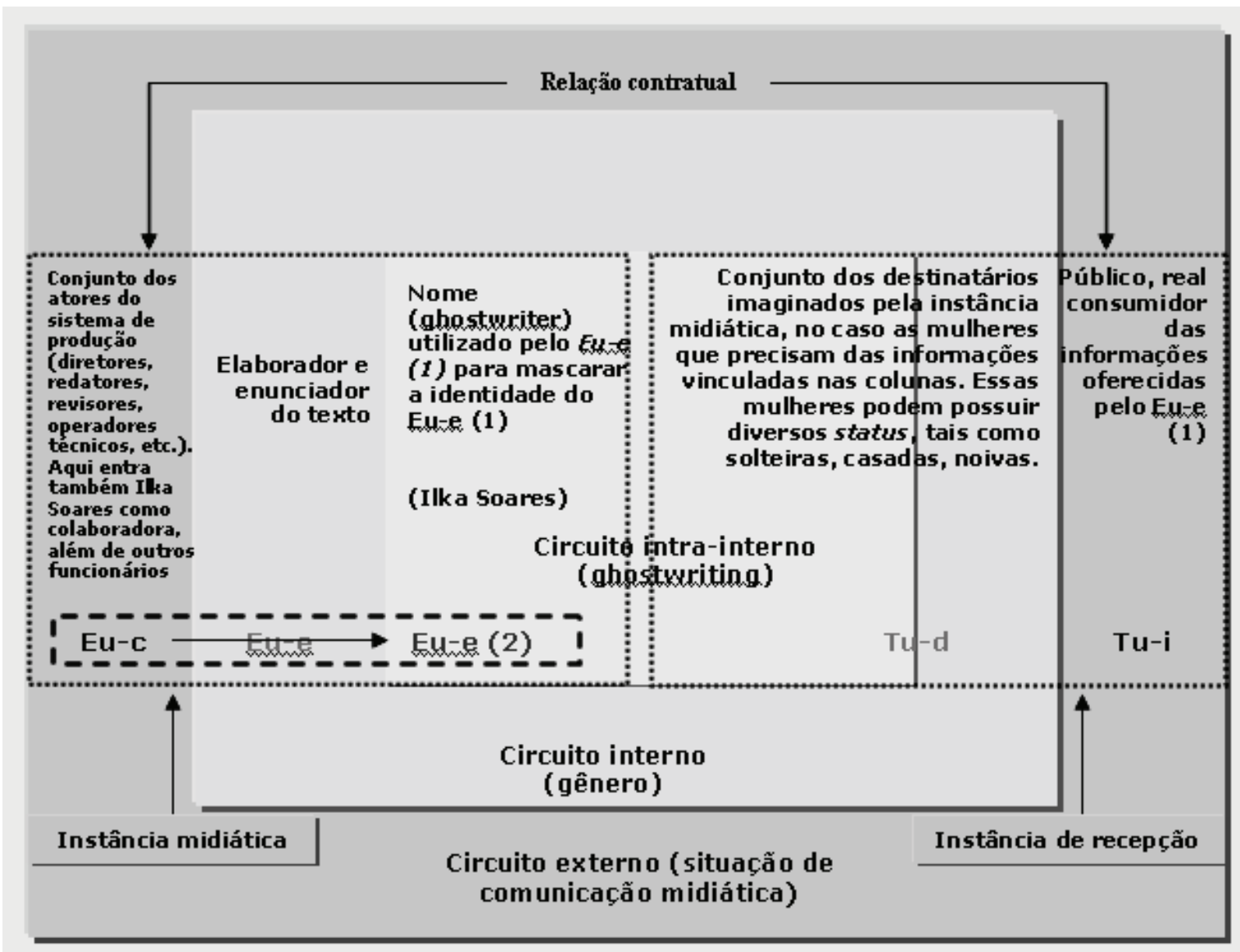

Figura 3 - Quadro enunciativo referente à coluna "Só para Mulheres".

O aparecimento do EUe (2) no âmbito dessa organização enunciativa permite que o público leitor perceba esse ser discursivo como um ser psicossocial, que tem uma existência real no mundo fenomênico, embora para a instância midiática esse ser seja somente uma estratégia discursiva de mascaramento, encenação e captação midiática, não constituindo para ela, portanto, nem num ser discursivo nem num ser psicossocial. A utilização do pseudônimo oscila, então, entre dois pontos: (i) um que faz crer ao TUd que quem fala é um sujeito psicossocial que não corresponde ao sujeito psicossocial real e nem o sujeito enunciador real; (ii) um mascaramento identitário que faz a instância midiática adotar o pseudônimo como um meio de não comprometer o $E U_{c}$ aos textos que ele escreve. ${ }^{10}$

\footnotetext{
${ }^{10}$ Nunes (2006) afirma que Clarice Lispector utilizava pseudônimos neste tipo de publicação como um meio de não comprometer sua carreira literária. Por se tratar, na época, de uma escritora não muito conhecida pelo grande público e também por considerar os textos da imprensa feminina
} 
Já o esquema retratado na figura 3 refere-se ao gênero Teste no âmbito da coluna "Só para Mulheres", cuja assinatura era a de Ilka Soares.

No início da década de 60, o jornal Diário da Noite passava por diversas crises e uma das estratégias utilizadas para reverter tal quadro foi o apelo à credibilidade de personalidades famosas que, embora não escrevessem de fato os textos das colunas do jornal, assinavam várias delas. Nesse contexto, Ilka Soares aparece como uma dessas personalidades que colaboravam com tal jornal através da assinatura de uma de suas colunas: "Só para Mulheres", enquanto Clarice se apresenta como a elaboradora e escritora dos textos desta última.

Assim, para o gênero Teste, em tal coluna, temos, em termos de identidade, que: (i) o $E U c$, como no caso da coluna "Correio Feminino Feira de Utilidades", é o conjunto de atores envolvidos na prática jornalística, porém aqui devemos englobar além de Clarice Lispector, a atriz Ilka Soares, visto ser essa última uma das colaboradores do jornal; (ii) o EUe (1) é o sujeito enunciador do teste, e nesse caso Ilka Soares não aparece, pois quem realmente enuncia é Clarice; ${ }^{11}$ (iii) o EUe (2) é a assinatura ou o nome utilizado pelo $E U e$ (1) para mascarar a sua própria identidade, pois, pretende-se criar o efeito de que quem fala é o sujeitocomunicante Ilka Soares, logo, no plano discursivo, o EUe (2) é também um ser estratégico que pretende encenar a identidade psicossocial de Ilka Soares, evidenciando, com isso, um desdobramento entre o $E U_{c}$ e o $E U_{e}$ (2) mediado pelo $E U_{e}$ (1) (linhas pontilhadas entre o $E U_{c}$ e o $\left.E U_{e}(2)\right)$; (iv) o TUi, como no caso da seção de Helen Palmer, compõe-se das mulheres que leem as colunas femininas; (v) o $T U d$, o destinatário-alvo do gênero, constitui-se das mulheres que precisam checar, através das perguntas propostas pelos testes, se se enquadram no estereótipo encenado no âmbito do gênero.

Nesse esquema também percebemos a presença de duas instâncias em relação de intersubjetividade: (i) a instância de produção midiática, formada pelo $E U_{c}$, pelo $E U_{e}$ (1) e pelo $E U_{e}(2)$, e (ii) a instância de recepsão,

\footnotetext{
como segregados, Clarice recorreu aos pseudônimos como uma forma de não comprometimento, visto que sentia que esses textos não eram adequados.

${ }^{11}$ Vale ressaltar, contudo, que como elaboradora dos testes Clarice não é mais o ser psicossocial que constitui o $E U c$, mas um ser discursivo, responsável pela encenação discursiva, e que recebe influência deste último.
}

CORRÊA-ROSADO; MELO - "Você está pronto para testar-se?"... 
constituída pelos TUd e TUi. O EUe (2) deste esquema apresenta funções similares ao $E U e$ (2) do esquema apresentando pela figura 2, porém em vez de funcionar como uma forma de mascaramento identitário do $E U c$, funciona como um meio de mascarar a identidade do EUe (1). Na coluna "Só para Mulheres", contudo, esse EUe (2) faz alusão ao um ser psicossocial real, no caso a atriz e manequim Ilka Soares, enquanto em "Correio Feminino - Feira de Utilidades" o nome Helen Palmer é somente um pseudônimo, isto é, o ser Helen Palmer não existe no plano psicossocial. Essa alusão à atriz em questão pode levar o ato de linguagem a encenar um efeito de realidade no âmbito discursivo, pois, para o TUi a impressão que se tem é a de que quem enuncia é a própria Ilka Soares, embora a instância midiática saiba que tal impressão constitui-se como uma estratégia discursiva.

Toda essa troca linguageira entre os interlocutores é realizada em circunstâncias materiais concretas que, de alguma maneira, influenciam essa situação de comunicação. Como já apontamos anteriormente, Charaudeau (1992) estabelece um conjunto de perguntas que objetivam configurar o quadro material que envolve o ato de comunicação, além de demonstrar os traços contratuais que estão em jogo. Aqui, para análise das circunstâncias materiais do gênero em estudo, vamos só considerar as perguntas referentes às características físicas do ato, pois as demais, características identitárias e contratuais, já foram e/ou serão discutidas ao longo deste trabalho. Dentre as perguntas propostas por Charaudeau (1992), com relação aos parceiros, temos:

- Eles estão presentes fisicamente um ao outro, ou não?

- Eles são únicos ou múltiplos?

- Eles estão próximos ou longes um do outro, e como estão eles dispostos um com relação ao outro?

Já com relação ao canal de transmissão, temos as seguintes perguntas:

- Ele é oral ou escrito?

- Ele é direto ou indireto (telefone, rádio)?

- Qual outro código semiológico é utilizado (imagem, grafismo, sinais, gestos, etc)? 
Respondendo a essas perguntas, percebemos que o gênero Teste, como um reflexo do próprio domínio midiático, caracteriza-se pela ausência física entre os parceiros, isto é, EUc e TUi não se veem e não se tocam, além de serem ambos múltiplos, pois são, respectivamente, componentes da instância midiática e da instância de recepção. Como consequência dessa ausência física, temos a distância que esses interlocutores têm um com relação ao outro, além do próprio canal por eles utilizado, que no caso é o escrito. Esse canal escrito é disposto de forma direta dentro de um suporte, o jornal. No jornal, encontramos as colunas femininas de Clarice, que no caso do gênero em estudo, são as colunas, "Só para Mulheres" (Diário da Noite) e "Correio Feminino Feira de utilidades" (Correio da Manhã). A figura 4, a seguir, é um fac-simile da seção "Correio Feminino - Feira de Utilidades". Através dessa figura podemos visualizar um pouco melhor as informações arroladas sobre as circunstâncias materiais do gênero situacional teste.

Quando questionamos, contudo, sobre os possíveis códigos semiolinguísticos utilizados pelo $E U c$, uma falha pode ser apontada, falha justificada pelo fato de utilizarmos como corpus de uma pesquisa, os textos da coletânea Correio Feminino e não os textos do jornal. Dessa forma, não podemos afirmar que, se além do código linguístico, o $E U_{c}$ utilizou algum outro código para compor o quadro material do gênero. Só sabemos que, como apontou Nunes (2006), para o jornal Diário da Noite, Clarice utilizava algumas figuras e/ou fotos para fazer a diagramação da página.

Portanto, com relação aos aspectos situacionais e contratuais do gênero Teste temos que o $E U e(1)$, criando um outro ser (EUe (2)), dirige-se a um TUd com uma finalidade, averiguar se esse último possui traços comportamentais e pessoais exigidos pelos padrões então vigentes, selecionando para isso três visadas, visada de informação, visada de incitação e visada de instrução que, por sua vez, relacionam-se com um propósito, comportamento e personalidade, dentro de uma situação de comunicação puramente midiática. 


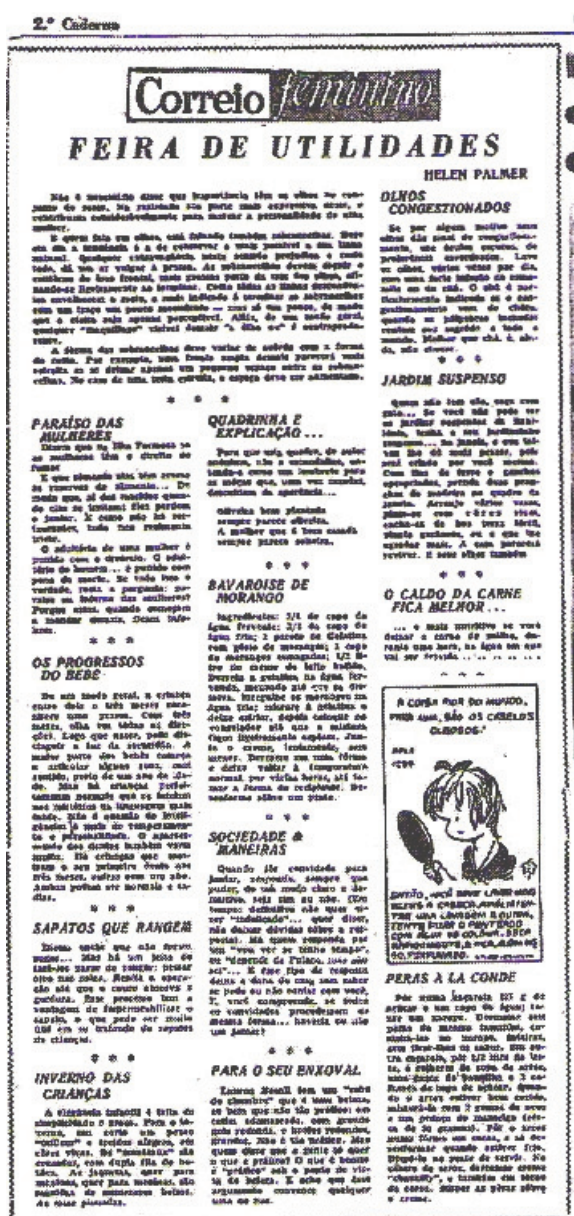

Margaref é uma espósa feliz

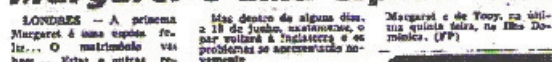

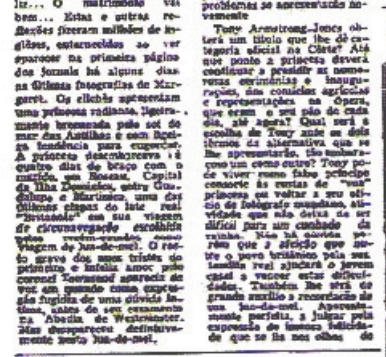

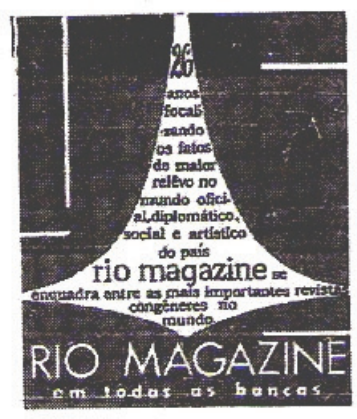

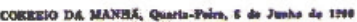
Pes chatos parecem
esquios em sapalo
apropriado

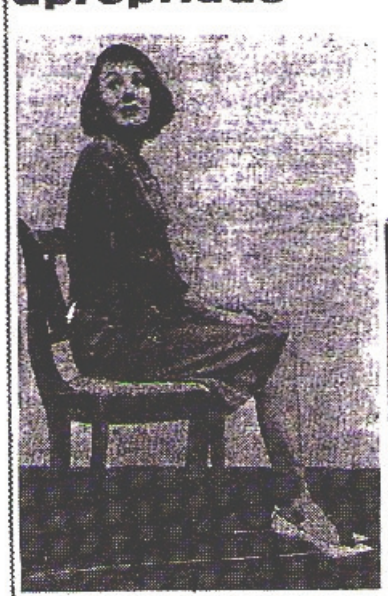

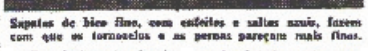

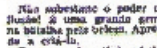

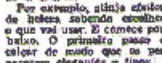

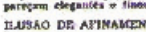

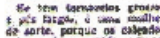

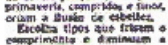

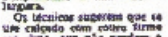
$=$ intion

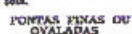

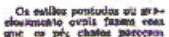

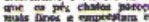

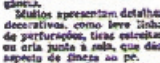

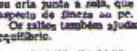
wan CIIDE DE SI MESMA

por que a evitam?

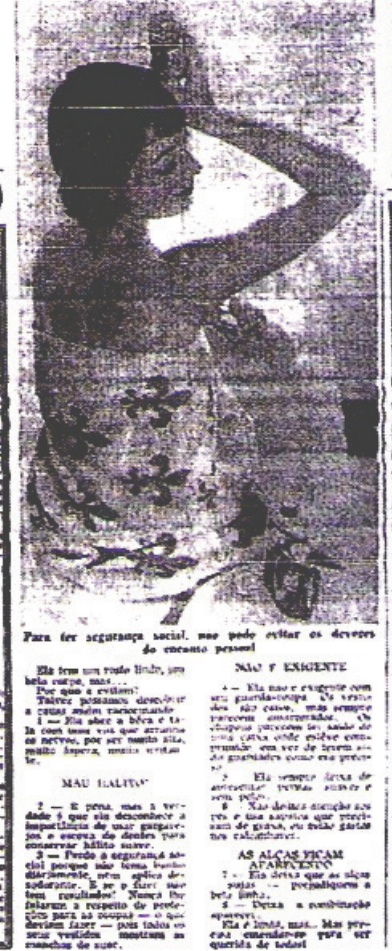

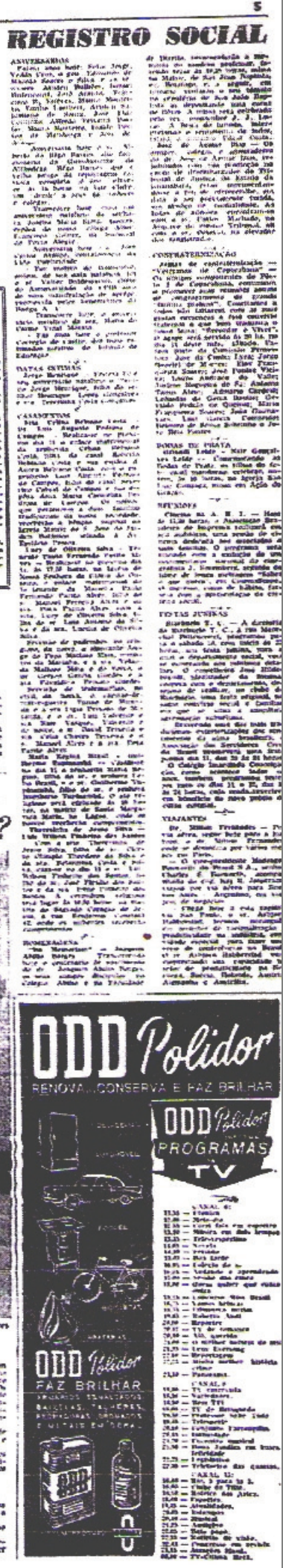

Figura 4 - Fac-simile da seção "Correio Feminino - Feira de Utilidades", publicada em 05 de junho de 1960 (NUNES, 2006, p. 198). 


\subsection{O gênero Teste e suas restrições discursivas: uma questão de modos discursivos}

A finalidade do gênero Teste, ao selecionar suas visadas de informação, incitação e instrução, organiza-se através de dois modos de organização do discurso: (i) o modo de organização enunciativo e (ii) o modo de organização descritivo. Porém, pelo fato desses modos serem constituídos por vários componentes, deixamos suas configurações para outros momentos. ${ }^{12}$

Considerando que o EUe (1) assume o papel linguageiro de conhecedor e testador da natureza feminina da mulher, determinando, por conseguinte, um papel de ser testado ao $T U d$, como as identidades assumidas pelos protagonistas dentro do gênero em estudo, percebemos que o EUe se utiliza de vários modos enunciativos para demonstrar tal identidade.

Dentre os três modos enunciativos apontados por Charaudeau (1983), modo ou comportamento alocutivo, modo ou comportamento elocutivo e modo ou comportamento delocutivo, no gênero Teste, em Correio Feminino, o $E U e$ (1), através de seu EUe (2), utiliza-se dos comportamentos alocutivo e delocutivo, como mostram os exemplos (6), (7) e (8) abaixo:

(6) Quando sai do restaurante, vai à frente da companheira? (A senhora deve precedê-lo à saída). (TES1)

(7) Se casar-se agora significasse, por razões financeiras, viver com seus sogros, você preferiria adiar o casamento? (TES2)

(8) Faça uma lista de cores, $1^{\circ}$ as de sua preferência, em ordem decrescente; $2^{\circ}$ as de que não gosta, sempre em ordem decrescente; e em $3^{\circ}$ as que lhe são indiferente. (TES3)

Pelos exemplos percebemos que, de um lado, o comportamento alocutivo, com o qual o locutor implica o seu interlocutor em um determinado fazer, determina, para o primeiro o papel linguageiro daquele que sabe "o que fazer", "como fazer", "onde fazer" e "por que fazer". Isso pode ser demonstrado por meio das próprias sequências

\footnotetext{
${ }^{12}$ Para uma melhor visualização dos modos enunciativo e descrito do gênero Teste no corpus em questão, ver os artigos de Corrêa-Rosado e Melo (2008a), Organização enunciativa em Correio Feminino: um estudo do gênero Teste sob o olhar da teoria Semiolinguistica; e Corrêa-Rosado e Melo (2008b), Organização descritiva do gênero Teste em Correio Feminino de Clarice Lispector.
}

CORRÊA-ROSADO; MELO - "Você está pronto para testar-se?"... 
interrogativas que constituem um aspecto formal do gênero (exemplos (f) e $(\mathrm{g})$ ): as sequências interrogativas dos textos do gênero Teste revelam que as informações são conhecidas pelo $E U e$ (1) e que elas são importantes para o $T U d$, pois promovem algum benefício a ele. Nesse sentido, ao implicar o $T U d$, o EUe (1) determina para aquele um papel linguageiro de alguém que precisa saber, isto é, uma posição de inferioridade em relação ao EUe.

Por outro lado, o EUe (1) utiliza o comportamento delocutivo, com o qual ele não implica nem a si próprio e nem o $T U d$, criando um efeito de distanciamento do dito, esse promove a credibilidade do discurso, visto que o EUe (1) deixa, na maioria dos textos, os manuais de etiqueta e comportamento da época "falarem mais alto". Vejamos os seguintes exemplos:

(9) Quando passeia com uma senhora e um amigo, ele enquadra a senhora entre os dois ou anda junto do amigo? (A senhora fica entre os dois cavalheiros). (TES1)

(10) VERDE - Positivo: não é influenciável. Negativo: tem a necessidade incessante de libertar-se. Indiferente: não teme a solidão. (TES3)

Desse modo, ao assumirem discursivamente as suas identidades, através dos comportamentos enunciativos, o EUe (1), visando um efeito discursivo, seleciona o seu propósito, recortando-o através dos modos de tematização, que dividem os temas, comportamento e personalidade, nos sub-temas: (i) polidez (TES1); (ii) casamento (TES2); e (iii) as cores e a personalidade (TES3).

Além disso, as circunstâncias materiais do gênero teste são responsáveis, discursivamente, pela semiologização praticamente verbal do gênero.

\subsection{O gênero Teste e suas restrições formais: uma questão de construção}

Quanto às restrições formais do gênero Teste, percebemos que a composição textual interna do mesmo é caracterizada por três partes fundamentais: (i) Instrução, (ii) Perguntas e (iii) Respostas. 
A primeira seção é geralmente localizada no início do Teste. No exemplo em anexo, a seção instrução é posicionada acima da seção de perguntas. É nessa seção que o interlocutor irá encontrar os "comandos" necessários para realizar os procedimentos do Teste:

(11) Quanto maior número de vezes você responde "sim" às perguntas que se seguem, mais pronta você está. Só vale a "sim" verdadeiro, sincero... (TES2)

A segunda seção, Perguntas, é o Teste propriamente dito, pois nela encontram-se as perguntas que o interlocutor deve responder para checar a sua personalidade e os seus comportamentos:

(12) Você acha que ter namorados está perdendo a graça? (TES2)

A terceira e última seção, Respostas, apresenta as respostas apropriadas a cada uma das perguntas propostas. No texto em anexo, o teste Você está pronta para casar-se?, essa última seção não aparece no corpo do texto, visto que, todas as perguntas são sequências interrogativas de sim ou não e que por isso o resultado do teste é obtido pelo somatório dos "sins", tornando a exibição de respostas individuais desnecessárias.

Entretanto, os nomes dessas seções são de certa forma hipotéticos. Na verdade, nenhum dos textos identificados como gênero Teste apresenta algum título que remeta a uma das seções acima. Porém, conseguimos identificá-las pela recorrência de certas construções gramaticais em cada uma delas.

Dessa forma, em termos de construção gramatical, a seção perguntas se organiza através de construções interrogativas, sejam elas informativas ou de sim ou não, a seção respostas se utiliza geralmente de construções gramaticais impessoais, enquanto a seção de instrução é caracterizada pela forte presença de frases imperativas. Vejamos alguns exemplos:

(13) Ele desce do ônibus ou do bonde, antes ou depois de uma senhora? (Desce antes para ajudar a senhora descer confortavelmente). (TES1)

(14) Você e seu noivo acham certo o exame pré-nupcial? (TES2) 
(15) Não seja demasiado exigente com os modos "dele". Mas se você quiser ajudar seu marido a parecer mais polido, faça com ele esse teste, e vejam os dois em que adiantamento ele está. (TES1)

(16) Faça uma lista de cores, $1^{\circ}$ as de sua preferência, em ordem decrescente; $2^{\circ}$ as de que não gosta, sempre em ordem decrescente; e em $3^{\circ}$ as que lhe são indiferentes. (TES3)

Portanto, as restrições formais do gênero Teste revelam que o mesmo é divido em três partes, Instrução, Perguntas e Respostas, essas partes sendo delimitadas por construções gramaticais específicas, como as construções interrogativas para a seção perguntas, as construções impessoais para a seção respostas e as construções imperativas para a seção instrução.

\section{CONSIDERAÇÕES FINAIS}

O presente trabalho apresentou a configuração do gênero Teste, no âmbito da obra Correio Feminino de Clarice Lispector. Essa configuração tentou evidenciar, a partir dos pressupostos teóricos metodológicos da AD Semiolinguística, os diferentes aspectos dos três níveis deste gênero: os aspectos do nível situacional, os aspectos do nível discursivo e os aspectos do nível formal.

Em termos situacionais, o gênero Teste - que foi analisado como um gênero veiculado ao suporte jornal (mídia de imprensa), ou seja, como uma situação de comunicação particular do domínio midiático - é um gênero cuja finalidade é propor ao interlocutor uma série de perguntas, relacionadas aos propósitos de personalidade e comportamento, para que esse último possa averiguar se está de acordo com os padrões sociais exigidos. Essa mesma finalidade ainda seleciona três visadas para determinar a expectativa dessa situação de comunicação: visada de informação, visada de incitação e visada de instrução. Além disso, as restrições situacionais revelam que esse gênero coloca em relação de intersubjetividade duas instâncias: uma de produção, composta pelo $E U c$, pelo $E U e$ (1) e pelo $E U e$ (2), e uma instância de recepção, composta pelos TUd e TUi. 
As restrições discursivas apontam que o gênero é caracterizado pelos modos enoncivos, enunciativo e descritivo, pelos modos enunciativos, alocutivo e delocutivo, pelos modos de tematização, polidez, casamento e personalidade, e pelo modo de semiologização verbal.

Em relação às restrições formais, observa-se que o gênero é divido em três partes básicas, instrução, perguntas e respostas, essas sendo caracterizadas não por títulos, mas por construções gramaticais específicas, como as construções imperativas para a instrução, as construções interrogativas para as perguntas, e as construções impessoais para as respostas.

\section{REFERÊNCIAS}

BUITONI, D. H. S. Mulher de papel: a representação da mulher na imprensa feminina brasileira. São Paulo: Edições Loyola, 1981.

Imprensa feminina. São Paulo: Ática. 1986.

CHARAUDEAU, P. Langage et discourse: éléments de sémiolinguistique (théorie et pratique). Paris: Hachette, 1983.

Grammaire du sens et de l'expression. Paris: Hachette, 1992.

Visadas discursivas, gêneros situacionais e construção textual. Tradução de Renato de Melo. In: MACHADO, I. L.; MELLO, R. (Orgs.). Gêneros: reflexões em análise do discurso. Belo Horizonte: NAD/FALE/UFMG, 2004. p. 13-41.

. Discurso das mídias. Tradução de Angela M. S. Corrêa. São Paulo: Contexto, 2006 .

Discurso político. Tradução de Angela M. S. Corrêa. São Paulo: Contexto, 2006b.

CORRÊA-ROSADO, L.C.; MELO, M. S. S. Organização enunciativa em Correio Feminino: um estudo do gênero teste sob o olhar da teoria semiolinguística. Revista Vertentes, São João Del Rey, MG, v. 1, n. 32, p. 202-214, jul./dez. 2008a. 
Organização descritiva do gênero teste em Correio Feminino de Clarice

Lispector. Revista Glauks, Viçosa, MG, v. 9, n. 1, p. 156-174, jan./jun. 2008b.

LISPECTOR, C. Correio Feminino. Rio de Janeiro: Rocco, 2006.

NUNES, A. M. Clarice Lispector jornalista: páginas femininas e outras páginas. São Paulo: Editora Senac, 2006.

. Uma aprendizagem ou as páginas femininas de Clarice Lispector.

Revista da Anpoll, Brasília, DF, v. 25, p. 267-290, jan./jul. 2008.

RABAÇA, C. A.; BARBOSA, G. Dicionário de comunicação. São Paulo: Ática, 1995.

\section{ANEXO}

\section{VOCÊ ESTÁ PRONTA PARA CASAR-SE?}

(Diário da Noite, 10 de agosto de 1960)

Quanto maior número de vezes você responde "sim" às perguntas que se seguem, mais pronta você está. Só vale a "sim" verdadeiro, sincero...

- Você acha que ter namorados está perdendo a graça?

- Sente que pode resolver problemas sem consultar sua mãe ou seu pai?

- Você e seu noivo já concordaram quanto à religião?

- Você evita planos de reformar ou corrigir seu futuro marido depois do casamento?

- Você acha que terá prazer em ficar muitas noites em casa, ocupada com pequenas tarefas domésticas, se não estiverem ao seu alcance muitas saídas?

- Se casar-se agora significasse, por razões financeiras, viver com seus sogros, você preferiria adiar o casamento?

- Você dispensaria um vestido novo ou um artigo de luxo em favor de um objeto para a casa?

- Você adiaria a "casa ideal" em prol da casa prática e realística que suas posses permitem?

- Você e seu noivo acham certo o exame pré-nupcial? 
Recebido em 30/09/08. Aprovado em 08/06/09.

Title: "Are you ready to test yourself?": a semiolinguistic approach to the quiz genre in Clarice Lispector's Correio Feminino

Author: Leonardo Coelho Corrêa Rosado; Mônica Santos de Souza Melo

Abstract: The aim of this paper is to characterize, based on the theoretical and methodological assumptions of Semiolinguistic Discourse Analysis, the genre Quiz within Clarice Lispector's collection of journalistic texts, Correio Feminino. This approach looks at genres from the viewpoint of its situational, discursive and formal constraints. The results show that the Quiz, in the corpus under analysis, is a media genre intended to question the reader on aspects of his/her personality and behavior, through a series of informational, encouraging and instructional questions. The genre, in its discursive and formal levels, is characterized by the presence of descriptive and enunciative organizational modes, as well as by some impersonal grammatical structures.

Keywords: Semiolinguistics; situational genres; Clarice Lispector; quiz.

Titre: "Êtes-vous prêt à vous remettre en question?": une approche sémiolinguistique du genre test dans le "Correio Feminino" de Clarice Lispector

Auteur: Leonardo Coelho Corrêa Rosado; Mônica Santos de Souza Melo

Résumé: L'objectif de ce travail est celui de faire la configuration, à partir des présupposés théorico-méthodologiques de l'AD Sémiolinguistique, le genre Test dans le domaine du recueil de textes journalistiques de Clarice Lispector, "Correio Feminino". Cette configuration remarque le genre à partir de ses restrictions dans les niveaux situationnels, discursif et formel. Les résultats démontrent que le genre test, dans le corpus en l'occurrence, s'agit d'un texte médiatique qui a comme finalité proposer quelques argumentations à l'interlocuteur sur des aspects liés à sa personnalité et à son comportement, par le moyen d'une série des questions, tout en sélectionnant les visées d'information, incitation et instruction. Le genre, dans son niveau discursif et formel, se caractérise par la présence des moyens d'organisation descriptive et énonciative, et aussi par quelques constructions grammaticales impersonnelles.

Mots-clés: genres situationnels; sémiolinguistique; Clarice Lispector; test.

Título: ¿"Usted está listo para probarse?”: un abordaje semiótico-linguístico del género prueba en el Correo Femenino de Clarice Lispector

Autor: Leonardo Coelho Corrêa Rosado; Mônica Santos de Souza Melo

Resumen: El objetivo de este trabajo es configurar, a partir de los supuestos teóricometodológicos de la AD Semiótico-linguístico, el género Prueba en el ámbito del conjunto de textos periodísticos de Clarice Lispector, Correo Femenino. Esa configuración observa el género a partir de sus restricciones en los niveles situacional, discursivo y formal. Los resultados muestran que el género prueba, en el cuerpo en estudio, es un texto mediático que tiene por finalidad proponer algunos cuestionamientos al interlocutor sobre aspectos ligados a su personalidad y a su comportamiento, a través de una serie de preguntas, seleccionando las visadas de información, incitación e instrucción. El género, en su nivel discursivo y formal, se

CORRÊA-ROSADO; MELO - "Você está pronto para testar-se?"... 
caracteriza por la presencia de los modos de organización descriptivo y enunciativo, bien como por algunas construcciones gramaticales impersonales.

Palabras-clave: géneros situacionales; semiótico-linguístico; Clarice Lispector; prueba. 